\title{
In infertile women, cells from Chlamydia trachomatis infected site release higher levels of interferon-gamma, interleukin- 10 and tumor necrosis factor-alpha upon heat shock protein stimulation than fertile women
}

\author{
Pragya Srivastava1 ${ }^{1}$ Rajneesh Jha ${ }^{1}$, Sylvette Bas ${ }^{2}$, Sudha Salhan ${ }^{3}$ and
} Aruna Mittal*1

Address: ${ }^{1}$ Institute of Pathology - ICMR, Safdarjung Hospital Campus, Post Box no. 4909, New Delhi-110 029, India, ${ }^{2}$ Division of Rheumatology, Department of Internal Medicine, University Hospital, 1211 Geneva 14, Switzerland and ${ }^{3}$ Department of Gynecology \& Obstetrics, Safdarjung Hospital, New Delhi-110 029, India

Email: Pragya Srivastava - pragyasr@rediffmail.com; Rajneesh Jha - rjha_molbio@rediffmail.com; Sylvette Bas - sylvette.bas@hcuge.ch; Sudha Salhan - sudhasalhan@rediffmail.com; Aruna Mittal* - amittal_cp@rediffmail.com

* Corresponding author

\section{Published: 20 May 2008}

Reproductive Biology and Endocrinology 2008, 6:20 doi:10.1/86/1477-7827-6-20

This article is available from: http://www.rbej.com/content/6/1/20

(C) 2008 Srivastava et al; licensee BioMed Central Ltd.

This is an Open Access article distributed under the terms of the Creative Commons Attribution License (http://creativecommons.org/licenses/by/2.0), which permits unrestricted use, distribution, and reproduction in any medium, provided the original work is properly cited.
Received: 17 March 2008

Accepted: 20 May 2008

\begin{abstract}
Background: The magnitude of reproductive morbidity associated with sexually transmitted Chlamydia trachomatis infection is enormous. Association of antibodies to chlamydial heat shock proteins (cHSP) 60 and 10 with various disease sequelae such as infertility or ectopic pregnancy has been reported. Cellmediated immunity is essential in resolution and in protection to Chlamydia as well as is involved in the immunopathogenesis of chlamydial diseases. To date only peripheral cell mediated immune responses have been evaluated for cHSP60. These studies suggest cHSPs as important factors involved in immunopathological condition associated with infection. Hence study of specific cytokine responses of mononuclear cells from the infectious site to $\mathrm{cHSP} 60$ and $\mathrm{cHSPIO}$ may elucidate their actual role in the cause of immunopathogenesis and the disease outcome.
\end{abstract}

Methods: Female patients $(n=368)$ attending the gynecology out patient department of Safdarjung hospital, New Delhi were enrolled for the study and were clinically characterized into two groups; chlamydia positive fertile women $(n=63)$ and chlamydia positive infertile women $(n=70)$. Uninfected healthy women with no infertility problem were enrolled as controls $(n=39)$. cHSP60 and cHSPIO specific cytokine responses (Interferon (IFN)-gamma, Interleukin (IL)-10, Tumor Necrosis Factor (TNF)-alpha, IL13 and IL-4) were assessed by ELISA in stimulated cervical mononuclear cell supernatants.

Results: $\mathrm{CHSP60}$ and $\mathrm{CHSPI} 0$ stimulation results in significant increase in IFN-gamma $(\mathrm{P}=0.006$ and $\mathrm{P}=$ 0.04 respectively) and IL- 10 levels $(P=0.04)$ in infertile group as compared to fertile group. A significant cHSP60 specific increase in TNF-alpha levels $(P=0.0008)$ was observed in infertile group as compared to fertile group. CHSP60 and cHSPI0 specific IFN-gamma and IL- 10 levels were significantly correlated $(\mathrm{P}<$ $0.000 \mathrm{I}, r=0.54$ and $P=0.004, r=0.33$ respectively) in infertile group.

Conclusion: Our results suggest that exposure to chlamydial heat shock proteins (cHSP60 and cHSPI0) could significantly affect mucosal immune function by increasing the release of IFN-gamma, IL-I 0 and TNFalpha by cervical mononuclear cells. 


\section{Background}

Sexually transmitted Chlamydia trachomatis infection is an important public-health concern with major burden on female reproductive tract [1]. Untreated chlamydial infection can lead to pelvic inflammatory disease (PID) in 10\% to $40 \%$ of affected women, which can result in infertility, ectopic pregnancy and chronic pelvic pain [2].

Immune responses to $C$. trachomatis $60-\mathrm{kDa}$ heat shock protein (cHSP60) has been associated with the pathogenesis of $C$. trachomatis associated ectopic pregnancy and tubal infertility $[3,4]$. A recent report from our lab suggests that detection of anti-cHSP60 antibodies would help in the early prognosis of immunopathological sequelae in $C$. trachomatis infected women [5]. The stress response in Chlamydia reticulate bodies is characterized by cHSP60 induction and by reduction in major outer membrane protein and lipopolysaccharide (LPS) levels, as shown in an in vitro model of persistent infection [6,7]. This stress response is believed to interrupt the normal progression of reticulate bodies to infectious elementary bodies, resulting in a longer-term persistent infection. Such persistent infections may serve as antigenic reservoirs for potentially immunopathogenic anti-cHSP immune system responses [8]. The chlamydial $10-\mathrm{kDa}$ heat shock protein (cHSP10) is genetically linked to cHSP60; the two proteins bind to each other and prevent incorrect protein folding and denaturation. Thus, the pathogen's ability to survive stressful environmental conditions and persist in the host is maximized by cHSP60-cHSP10 expression.

The development of infertility is reported due to enhanced immune responses to $C$. trachomatis $[9,10]$. cHSP60 and cHSP10 antibodies seem to perform well in predicting tubal factor infertility (TFI) [11-17]. Cell-mediated immune responses to cHSP60 were demonstrated in women with PID and TFI [18-23]. Thus, immunopathogenesis of TFI also involves cell-mediated mechanisms. However, these studies were restricted to the peripheral immune responses. A recent study suggests that mucosal immune responses are better to predict pathogenesis as cervical cells are the actual cells encountering the pathogen [24]. In the previous report from our lab cHSP60 and cHSP10 specific proliferative responses were evaluated and suggested the probable role of cHSPs in modulation of mucosal immune responses [25]. Overall these studies suggest cHSPs specific cell mediated immune responses plays an important role in the immunopathogenesis associated with chlamydial infection. Hence it might be possible that cytokines released by cervical mononuclear cells that are in direct contact with the pathogens and with cHSPs may play a crucial role in the modulation of mucosal immune responses leading to pathogenesis. Therefore, the objective of this study was to characterize the cHSP60 and CHSP10 specific cytokine responses by cervical mononuclear cells among groups of women representing different clinical conditions, i.e. chlamydia positive fertile and infertile women for understanding their role in modulation of immune responses at the site of infection. The production of T helper type 1 (Th1)/Th2 cytokines was investigated as well as those of Tumor Necrosis Factor-alpha (TNF- $\alpha$ ) and Interleukin (IL)-10. The role of Th1/Th2 responses in the genital tract during Chlamydia infection is considered to be crucial for controlling the duration of infection and subsequent tubal pathology. Indeed, Th1 cells produce Interferon-gamma (IFN- $\gamma$ ) that promotes the destruction of Chlamydia [6] but can also promote inflammatory damage and fibrosis [26] whereas Th2 cells produce IL-4, IL-5, and IL-13 believed to be critical for defense against extracellular pathogens. The production of TNF- $\alpha$ and IL-10 was examined because their levels have been reported to be high in cervical secretions of $C$. trachomatis infected infertile women [27].

\section{Methods}

\section{Study population}

A total of 368 patients attending the gynecology out patient department, Safdarjung Hospital, New Delhi, India for gynecological complaints (cervical discharge, cervicitis and infertility) were enrolled in the study. The study received approval by the hospital's ethics review committee. Thirty-nine healthy age-matched controls attending the family-planning department for birth-control measures and with no previous history of any sexually transmitted disease (STD) were also enrolled. At recruitment, a detailed clinical questionnaire was administered to each patient for collecting information on reasons for referral, gynecology history including menstruation, symptoms of genital and urinary tract infection, obstetric and medical histories. Patients with positive urine pregnancy test, recent antibiotic therapy and history of recently treated sexually transmitted infection (STI) and genital tuberculosis were excluded from the study.

\section{Collection of samples}

The vulva was examined for lesions and vaginal/cervical discharge. The cervix was inspected for ulcers, warts, ectopy, erythema, discharge or any other abnormalities. After cleaning the endocervix with a cotton swab (Hi Media, Mumbai, India), endocervical swabs were collected from patients for diagnosis of C. trachomatis and other STI pathogens.

The cervical canal was wiped clean, and a cytobrush was placed within the endocervical canal so that cells from the endocervical region and the zone between the endocervical and ectocervical regions (transformation zone) could be obtained. The cytobrush was then held in a sterile centrifuge tube containing phosphate buffered saline (PBS) 
(pH 7.2) supplemented with $100 \mathrm{U}$ penicillin/ml, $100 \mu \mathrm{g}$ streptomycin $/ \mathrm{ml}$, and $100 \mu \mathrm{g}$ glutamine $/ \mathrm{ml}$. All cytobrush samples had negative results for blood contamination.

\section{Laboratory diagnosis}

Spots were made on glass slides from cervical swab samples. These were stained with fluorescein isothiocyanate conjugated monoclonal antibodies to C. trachomatis major outer membrane protein (MOMP) using Chlamydia trachomatis Direct Specimen Test kit (Microtrak, Syva Corporation, Palo Alto, CA, USA) according to the manufacturer's instructions. A sample was considered to be positive when at least 10 elementary bodies were detected. Samples with greater than one and less than 10 EBs were confirmed for positivity by polymerase chain reaction (PCR) analysis using a primer specific for 200 base pair (bp) plasmid of C. trachomatis [28]. Diagnosis for other STD pathogens were done by culture for Neisseria gonorrhoeae, Mycoplasma hominis, Ureaplasma urealyticum and by microscopy on gram stained smears for Candida sps., bacterial vaginosis, Trichomonas vaginalis as mentioned earlier [27].

\section{Cloning of $\mathrm{cHSP} 60$ and $\mathrm{cHSPIO}$}

Full-length cHSP60 gene (GenBank accession no. $\underline{\mathrm{M} 58027}$ ) was amplified using unique primer set (Forward primer - 5'-TCCCcccgggATGGTCGCTAAAAACATTAAA-3' and Reverse primer 5'-ACGCgtcgacTTAATAGTCCATTCCTGCGCC-3' with restriction endonuclease sites, XmaI and SalI respectively at 5'-end). Oligonucleotides used as primers were synthesized by Microsynth, Balgach, Switzerland. PCR products were initially cloned into pGEM-T Easy vector (Promega, Madison, Wisconsin) and checked for their correct reading frame by sequencing. The cloned inserts were then excised by digestion with restriction enzymes XmaI and SalI (New England Biolabs) and ligated to the compatible sites of the expression vector pQE-60 (Qiagen Inc., Chatsworth, California) in frame with a His 6 affinity tag-coding sequence at the 3 ' terminus. The resulting plasmids were introduced into Escherichia coli M15 cells and routinely grown in the presence of ampicillin $(100 \mu \mathrm{g} / \mathrm{ml})$ and kanamycin $(25 \mu \mathrm{g} /$ ml) (Sigma).

Cloning of cHSP10 and large-scale expression and purification of chlamydial recombinant proteins was performed as mentioned earlier [29]. Proteins under native conditions were purified by nickel chelate affinity chromatography (Qiagen Ni-NTA Superflow resin). The protein concentration was determined with the Bradford assay (Sigma). We controlled for the non-specific effects of LPS contamination by treating recombinant proteins with polymyxin B (Sigma-Aldrich). Purified proteins were subsequently characterized by SDS-PAGE and immunoblotting using monoclonal antibody against chlamydia
(Alexis Biochemicals, Lausen, Switzerland), separated into aliquots and frozen at $-80^{\circ} \mathrm{C}$.

\section{Purification and culture of cervical mononuclear cells}

Cervical specimens were vortexed before the removal of cytobrush. They were filtered through a 70- $\mu \mathrm{m}$ nylon cell strainer (Becton Dickinson, San Diego, CA, USA) and centrifuged at $200 \mathrm{~g}$ for $10 \mathrm{~min}$ and the cell pellet was resuspended in PBS. Mononuclear cells were separated by Ficoll-Paque density gradient centrifugation. The mononuclear cells were counted on haemocytometer and samples containing less than one million cells/ml were excluded. The mononuclear cells were washed three times with PBS and suspended in RPMI-1640 (Sigma-Aldrich) containing 5\% fetal calf serum (FCS) (PAA, Austria). Briefly, endocervical mononuclear cells were cultured in round-bottomed 96 -well plates $\left(5 \times 10^{4}\right.$ cells/well) in a total volume of $200 \mu \mathrm{l}$ and subsequently stimulated with cHSP60 $(2 \mu \mathrm{g} / \mathrm{ml})$ and cHSP10 $(3 \mu \mathrm{g} / \mathrm{ml})$ in triplicate. Phytoheamagglutinin (PHA $2 \mu \mathrm{g} / \mathrm{ml}$ ) (Sigma) was used as a positive control mitogen in each experiment. Optimum concentrations of antigen and mitogen were determined in preliminary experiments as optimum concentrations giving maximal proliferation post stimulation.

\section{Antibody assays}

Cervical washes of patients and controls were assayed for presence of IgG antibodies to cHSP60 and cHSP10. Briefly, the proteins were bound to the wells of a microtitre plate $(1 \mu \mathrm{g} /$ well $)$ in carbonate buffer $(14.2 \mathrm{mM}$ $\mathrm{Na}_{2} \mathrm{CO}_{3}, 34.9 \mathrm{mM} \mathrm{NaHCO}, 3.1 \mathrm{mM} \mathrm{NaN}_{3}, \mathrm{pH}$ 9.5) and were incubated overnight at $4^{\circ} \mathrm{C}$. After washing, wells were blocked with PBS- $0.5 \%$ bovine serum albumin (BSA) at $37^{\circ} \mathrm{C}$ for $60 \mathrm{~min} ; 100 \mu \mathrm{l}$ of cervical washes were then added, and after incubation at $37^{\circ} \mathrm{C}$ for $120 \mathrm{~min} 100$ $\mu \mathrm{l}$ of 1: 10000 dilution of peroxidase-conjugated goat antibody to human IgG (Jackson Immunoresearch, Baltimore, MD, USA) was added to each well. After further incubation of $60 \mathrm{~min}$ at $37^{\circ} \mathrm{C}$, the peroxidase substrate tetramethylene benzidine was added. The reaction was stopped with $0.5 \mathrm{M} \mathrm{H}_{2} \mathrm{SO}_{4}$ and the plates were read at 450 nm. Known positive and negative controls were always assayed in parallel to test samples. A positive sample was defined as one yielding an OD value that was at least 2 standard deviations (SD) above the mean value of known negative samples as mentioned earlier [30].

\section{Cytokine assays using ELISA}

Quantification of IFN- $\gamma$, IL-10, TNF- $\alpha$, IL-13 and IL-4 (ebiosciences, San Diego, CA, USA) in the supernatant of cervical mononuclear cell cultures of samples after $72 \mathrm{~h}$ stimulation with proteins was performed by commercially available ELISA kits, in accordance with the manufacturer's instructions. The minimum detectable cytokine concentrations for these assays were IFN- $\gamma-(4 \mathrm{pg} / \mathrm{ml})$, IL- 
$10-(2 \mathrm{pg} / \mathrm{ml})$, TNF- $\alpha-(4 \mathrm{pg} / \mathrm{ml}), \mathrm{IL}-13-(4 \mathrm{pg} / \mathrm{ml})$ and IL-4$(2 \mathrm{pg} / \mathrm{ml})$.

\section{Statistical analysis}

Since the distributions in cytokine production were not normal, differences between two groups were evaluated using Mann-Whitney $U$ test. A comparison between two groups was made only when the Kruskal-Wallis test yielded a statistically significant result. Categorical variables were compared using the $\chi^{2}$ test. Correlation was tested with Spearman's correlation coefficient.

\section{Results}

\section{Study population}

Cervical C. trachomatis infection was diagnosed by direct fluorescent assay (DFA)/PCR in 174 patients. Thirty-one of these patients were found to have bacterial vaginosis, or to be co-infected with either Candida sp., T. vaginalis, $M$. hominis, $U$. urealyticum or $N$. gonorrhoeae in the cervix and were thus excluded from the study. Ten Chlamydia positive patients were excluded, as the count of mononuclear cells in the cervical cells was less than 1 million cells/ml and epithelial cells were present. Based on diagnosis the women were divided into three groups. Group I $(n=39)$ comprised of uninfected healthy controls with no infertility problem; Group II $(\mathrm{n}=63)$ comprised of Chlamydia positive women with no infertility problem; Group III (n $=70$ ) comprised of Chlamydia positive women with infertility and who had laparoscopic or hysterosalpingographic evidence of tubal damage. Candidates were considered infertile if they had regular unprotected intercourse for at least 2 years without conception. The median ages of women in each group were comparable (Table 1).

\section{Detection of antibodies}

ELISA results showed that the prevalence was significantly higher for IgG antibodies to both cHSP60 ( $\mathrm{P}=0.04 \& \mathrm{P}<$ $0.0001)$ and cHSP $10(\mathrm{P}=0.03 \& \mathrm{P}<0.0001)$ in Group II and III respectively as compared to Group I. In Group III the prevalence was significantly higher for IgG antibodies to both cHSP60 and CHSP10 as compared to Group II (P $=0.002 \& \mathrm{P}=0.04$ respectively) (Table 1 ). Correlation between cHSP60 and cHSP10 specific IgG antibodies were significant $(\mathrm{P}=0.04, \mathrm{r}=0.26 \& \mathrm{P}<0.0001, \mathrm{r}=0.6)$ in both Group II and Group III respectively (Figure 1a \&1b).

\section{Cytokine production by stimulated cervical mononuclear cells}

IFN- $\gamma$ levels were significantly higher after stimulation with both cHSP60 and cHSP10 in Group II $(\mathrm{P}=0.04$ \& 0.02 respectively) and in Group III $(\mathrm{P}<0.0001)$ as compared to Group I. Significantly higher levels of IFN- $\gamma$ were observed after stimulation with both cHSP60 $(\mathrm{P}=0.006)$ and cHSP10 $(\mathrm{P}=0.04)$ in Group III when compared with Group II (Figure 2a). Similarly when IL-10 levels were compared significant difference was observed after stimulation with both cHSP60 and cHSP10 between Group II ( $P=0.03 \& 0.04$ respectively) and Group III $(\mathrm{P}=0.0005$ $\& 0.0007$ respectively) as compared to Group I and IL-10 was significantly higher $(\mathrm{P}=0.04)$ in Group III as compared to Group II after cHSP60 and cHSP10 stimulation (Figure 2b).

TNF- $\alpha$ levels were significantly higher after stimulation with cHSP60 and cHSP10 $(\mathrm{P}<0.0001 \& \mathrm{P}=0.02$ respectively) in Group III as compared to Group I whereas there was no significant difference $(P=0.07 \& 0.25$ respectively) in Group II as compared to Group I. The TNF- $\alpha$ levels were significantly higher $(P=0.0008)$ in Group III when stimulated with cHSP60 as compared to Group II. The TNF- $\alpha$ levels were higher although not significant ( $P$ $=0.1$ ) in Group III when stimulated with cHSP10 as compared to Group II (Figure 2c).

IL-13 levels were low (close to the minimum detectable cytokine concentrations) and no significant difference was observed after stimulation with both cHSP60 and cHSP10 in any group. There was no detectable IL-4 pro-

Table I: Prevalance of cHSP60 and cHSP IO specific antibodies in study population

\begin{tabular}{cccc}
\hline Groups & Age Median (range) & cHSP60-IgG & cHSP I0-IgG \\
\cline { 3 - 4 } & & Number (\%) \\
\hline Group I $(\mathbf{n = 3 9 )}$ & $25(21-37)$ & $3(8)$ & $2(5)$ \\
Group II $(\mathbf{n = 6 3 )}$ & $27(23-43)$ & $15(24)^{\mathrm{a}}$ & $13(21)^{\mathrm{b}}$ \\
Group III $(\mathbf{n}=\mathbf{7 0})$ & $29(21-42)$ & $35(50)^{\mathrm{c}, \mathrm{e}}$ & $26(37)^{\mathrm{d}, \mathrm{f}}$ \\
\hline
\end{tabular}

(n) represents number of patients

aP $=0.04$ as compared to Group I; $\mathrm{bP}=0.03$ as compared to Group I; $\mathrm{cP}<0.000$ I as compared to Group I; dP $<0.000$ I as compared to Group I; eP $=0.002$ as compared to Group II; $\mathrm{f}=0.04$ as compared to Group II where,

Group I-Healthy women with no infertility problem

Group II-Chlamydia positive women with no infertility problem

Group III-Chlamydia positive women with infertility

Categorical variables were compared using the $\chi^{2}$ test 
(a)

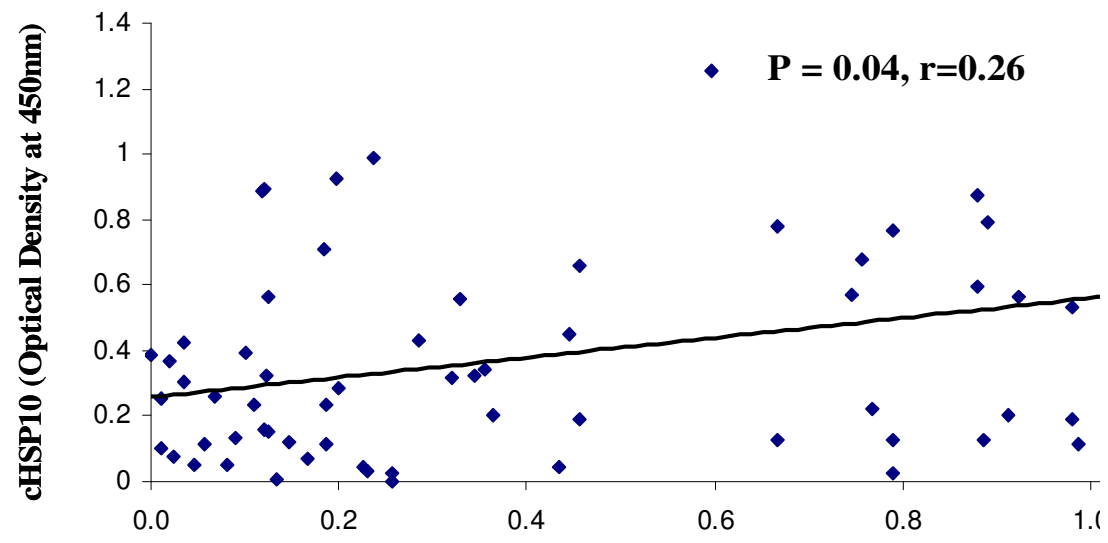

cHSP60 (Optical Density at 450nm)

(b)

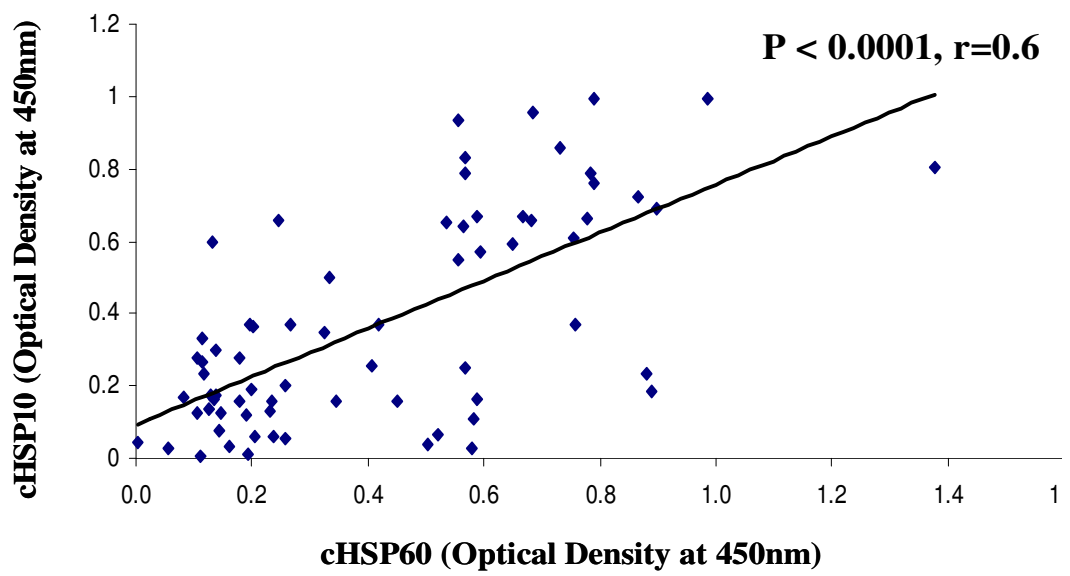

\section{Figure I}

Correlation of anti-cHSP60 and anti-cHSP I 0 IgG antibodies in cervical washes of patients. Scatter plot showing the correlation between anti-cHSP60 and anti-cHSPIO IgG antibodies among patients groups (a) Group II and (b) Group III. A significant correlation was observed in Group II as well as Group III where, Group II $(n=63)$ - Chlamydia positive women with no infertility problem. Group III $(n=70)$ - Chlamydia positive women with infertility. Correlation was tested with Spearman's correlation coefficient

duction in any culture supernatant after stimulation with both cHSP60 and cHSP10 (Data not shown).

IFN- $\gamma$ and IL-10 levels after stimulation with both cHSP60 and cHSP10 were significantly correlated in Group III (P $<0.0001, \mathrm{r}=0.54$ and $\mathrm{P}=0.004, \mathrm{r}=0.33$ respectively)

Median and range for cytokine concentration in all the groups after cHSP60 and cHSP10 stimulation are mentioned in Table 2.

Median and range for cytokine concentration after PHA stimulation were: IFN- $\gamma$ [Group I: 22 (0-276), Group II: 87 (5-643), Group III: 120 (11-1049)]; IL-10: [Group I: 20 (0-366), Group II: 69 (7-823), Group III: 104 (5-
669)]; TNF- $\alpha$ [Group I: 17 (0-114), Group II: 72 (0-445), Group III: 92 (0-382)]; IL-4 [Group I: 0 (0-2), Group II: 7 (0-25), Group III: 8 (0-18)]; IL-13 [Group I: 0.8 (0-5), Group II: 24 (0-86), Group III: 18 (0-63)].

There was high standard error for cytokines as one or two samples showed very high concentration of cytokines. However, these high values did not affect the median value as well as the significance of the results when data was analyzed excluding these values.

\section{Discussion}

Disease stages developed upon infection with Chlamydia are mediated by the immune responses. Immunity to $C$. trachomatis HSP60 and HSP10 is associated more typically 
(a)

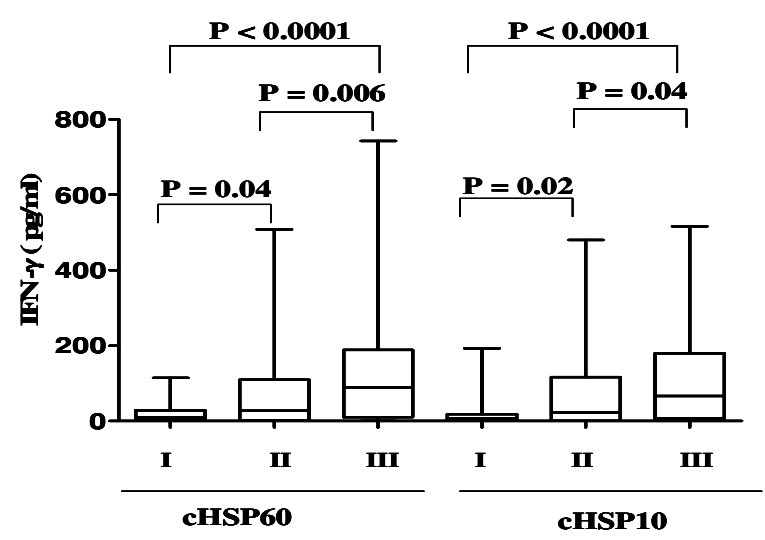

(b)
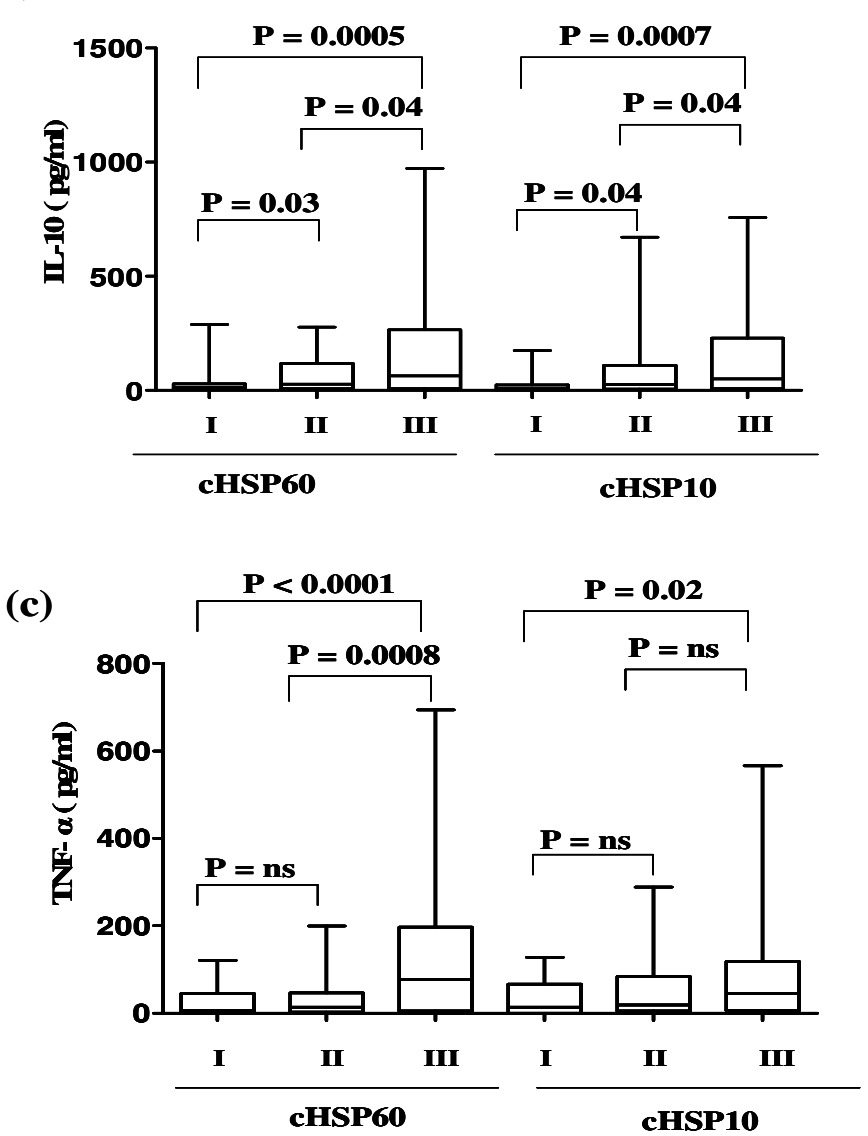

Figure 2

Cytokine concentrations after stimulation with cHSP60 and cHSP I0. Box plot representing concentrations of (a) IFN- $\gamma$ (b) IL-IO (c) TNF- $\alpha$ in supernatants of cervical mononuclear cells after stimulation with cHSP60 and cHSPI0. A significant increase in levels of IFN- $\gamma$, IL-I0 and TNF- $\alpha$ was observed after stimulation with cHSP60 and increased IFN- $\gamma$ and IL-I0 levels were observed after stimulation with cHSPIO in Group III as compared to Group I and Group II. The horizontal line in the middle of the box is the median value of the responses and the lower (upper) is the 25th (75th) percentile. I, II and III represent Group I, Group II and Group III respectively where, Group I $(n=39)$ - Healthy women with no infertility problem. Group II $(n=63)$ - Chlamydia positive women with no infertility problem. Group III $(n=70)$ - Chlamydia positive women with infertility. ns - Not significant. Mann-Whitney U-test was used for comparing two groups 
Table 2: Concentration $(\mathrm{pg} / \mathrm{ml})$ of cHSP60 and cHSP 10 specific cytokines in different groups.

\begin{tabular}{|c|c|c|c|c|c|c|}
\hline \multirow[t]{3}{*}{ Groups } & \multicolumn{2}{|c|}{ IFN- $\gamma$} & \multicolumn{2}{|c|}{ IL-IO } & \multicolumn{2}{|c|}{ TNF- $\alpha$} \\
\hline & cHSP60 & cHSPIO & cHSP60 & cHSPIO & cHSP60 & cHSPIO \\
\hline & \multicolumn{6}{|c|}{ Median (range) in $\mathrm{pg} / \mathrm{ml}$} \\
\hline Group I (n = 39) & II (0-II5) & $8(0-193)$ & $15(0-289)$ & $8(0-174)$ & $6(0-121)$ & $14(0-128)$ \\
\hline Group II $(n=63)$ & $28(0-508)$ & $24(0-480)$ & $27(0-278)$ & $26(0-67 I)$ & $14(0-199)$ & $19(0-289)$ \\
\hline Group III $(n=70)$ & $90(0-743)$ & $67(0-5 \mid 6)$ & $63(0-973)$ & $52(0-758)$ & $77(0-694)$ & $45(0-566)$ \\
\hline
\end{tabular}

(n) represents number of patients

Group I-Healthy women with no infertility problem

Group II-Chlamydia positive women with no infertility problem

Group III-Chlamydia positive women with infertility

with the chronic upper genital tract infection than it is with acute infection of the lower genital tract $[15,31]$.

In the present study we detected higher cHSP60 and cHSP10 specific IgG antibody responses in the cervical washes of infertile group as compared to fertile group. These results were consistent with the previous reports where recurrent infection group showed high prevalence of cHSP specific IgG and IgA antibodies [25]. We also found a significant correlation of cHSP60 and cHSP10 IgG antibodies suggesting that co-expression of cHSP60 and cHSP10 occurs at the site of infection too. This observation again adds to the previous reports suggesting cHSP10 is co-expressed with cHSP60 [32].

We also evaluated cHSP60 and cHSP10 specific cytokines in cervical mononuclear cells and found IL-10 levels were more prominent when stimulated with both cHSP60 and cHSP10 in the infertility group as compared with other groups. Our data is consistent with the previous studies in which cHSP60 specific higher IL-10 levels in pheripheral blood mononuclear cells (PBMCs) have been reported in infertile women [21]. Cohen et al had recently demonstrated that CHSP60 specific IL-10 production by PBMCs act as a risk factor for C. trachomatis infection in humans [22]. The enhanced levels of IL-10 may not be acting as anti-inflammatory mediator and might be involved in prolonging the infection by exerting immunostimulatory effects [33]. Overall, these results allow hypothesizing the role of IL-10 in fibrosis and tubal infertility. Indeed, IL-10 has been involved in fibrosis in several human diseases [34-36] and an association of fibrosis with cHSP60 and CHSP10 specific antibodies has been reported in infected animals [37].

We also evaluated IFN- $\gamma$ and TNF- $\alpha$ levels and higher levels of both the cytokines were detected in infertility group after stimulation with cHSP60 and CHSP10. IFN- $\gamma$ production has been identified as one of the main factors in protective immunity [38] and is also important in the development of chronic chlamydial infection [8]. IFN- $\gamma$ delays the developmental cycle of Chlamydia so that chlamydial reticulate bodies persist longer, which might result in persistent unapparent infection and also, play a role in immunopathogenesis by promoting inflammatory damage and fibrosis [26]. In addition, increased levels of IFN- $\gamma$ have been reported in the endocervical secretions of C. trachomatis positive infertile women [27]. TNF- $\alpha$ which displays antichlamydial properties [39], is also known to play an important role in the initiation of inflammatory response. In the mouse genital tract, infertility associated with endometriosis has been shown to be related to the production of TNF- $\alpha$ [40]. In human, both IFN- $\gamma$ and TNF- $\alpha$ have been reported to be associated with infertility [41-43]. Proinflammatory cytokines are also known to drive the lipid peroxidation of the spermatozoa plasma membrane to levels that can affect the sperm fertility capacity [44]. In addition TNF- $\alpha$ and IFN- $\gamma$ have effects on sperm motility, viability, membrane integrity and lateral head displacement, suggesting poor fertilizing potential of human spermatozoa during inflammatory conditions [45]. Previous evidence suggests that the concurrent immunization with cHSP60 switches the cytokine production of self HSP60 responding T cells to dominant production of proinflammatory IFN- $\gamma$ [46] showing that chlamydial HSP60 can break the tolerance of autoreactive cell reactions and lead them to participate in the inflammatory reactions during chlamydial disease. Hence from the present study higher levels of both IFN- $\gamma$ and TNF- $\alpha$ by cHSPs in infertility group may suggest their involvement in the immunopathological condition associated with the infertility.

In our study, IL-4 was undetectable and IL-13 levels were not significantly different in any group in contrast to previous report in which cHSP60 specific IL-13 in PBMCs has been reported to be associated with the protective response [22]. It may suggest that cHSP specific Th2 cytokines (IL-4 and IL-13) does not play any role in pathogenesis related to chlamydial infection. 
In our results high levels of IL-10 may not suggest a Th2 response as studies showed that it is secreted by Th1 and Th2 cells as well as other cells $[47,48]$. Further it has been shown that in many chronic infections in human and experimental animals, CD4 + T cells can produce high levels of both IL-10 and IFN- $\gamma$ [49]. Hence the production of high levels of both the cytokines, IL-10 and IFN- $\gamma$ in the absence of significant levels of other Th2 cytokines, suggests that the cells secreting IL-10 are not Th2 cells but other cells.

Previous studies, suggested that immune sensitization to HSPs probably require prolonged exposure of them at elevated concentrations [50]. As for cHSP60, there have been reports that during repeated and severe $C$. trachomatis infection there is enhanced recognition of cHSP60 by circulating lymphocytes $[18,51]$ and it has been shown that PBMCs from women with tubal factor infertility responded more frequently to cHSP60 antigen [21]. Hence the differential responses to cHSPs in chlamydia infected fertile and infertile women would be due to prolonged exposure to cHSPs in infertile cases.

We also did the correlation analysis of different cytokines produced against cHSP60 and cHSP10 and observed a positive correlation for IL-10 and IFN- $\gamma$ levels in infertility group suggesting similar role of cHSP10 in pathology associated with the infertility as cHSP60. There are no studies to date on cHSP10 specific cell mediated immune responses and our data suggests that the CHSP10 specific immune responses may have crucial role in the immunopathological condition associated with the infertility. Reports on the immunogenicity of HSP10 antigens from other microbial pathogens suggest that the HSP10 family of proteins are capable of eliciting chronic inflammation and delayed hypersensitivity. In particular, HSP10 homologues of Mycobacterium leprae and Mycobacterium tuberculosis have been shown to stimulate $\mathrm{T}$-cell responses $[52,53]$.

Overall our results suggest that exposure to the chlamydial heat shock proteins could significantly affect mucosal immune function by modifying the release of cytokines leading to severe immunopathological conditions related to infertility.

\section{Conclusion}

The intent of the study provides some perspective on the ways in which cHSPs may contribute to the disease process associated with chlamydial infections. From the present study it can be suggested that the enhanced HSP expression leads to antigen specific increase in IFN- $\gamma$, IL10 and TNF- $\alpha$ at the site of infection by cervical mononuclear cells suggesting cHSPs may consequently contribute to the immunopathogenesis associated with the infertil- ity. This study also points out that further research is warranted to more precisely define the potential contribution of cHSPlO and other conserved chlamydial antigens to the immunopathologic process associated with chlamydial infection.

\section{Competing interests}

The authors declare that they have no competing interests.

\section{Authors' contributions}

AM, PS and RJ had participated in the design of the study. The experiments were carried out by PS and RJ. Data analysis was performed by PS. SS had helped in collection of samples. AM and SB helped to draft the manuscript; the manuscript was written by PS. All authors have read and approved the final manuscript.

\section{Acknowledgements}

We thank Mrs Madhu Badhwar, Mrs Asha Rani and Mrs Rosamma Thomas for providing technical assistance. Funding for this study was supported by a grant from the Department of Biotechnology, Government of India (BT/ PR 4643/MED/I2/177/2004). We also acknowledge the Indian Council of Medical Research for providing financial assistance to Pragya Srivastava and Rajneesh Jha in the form of a research fellowship.

\section{References}

I. World Health Organization (WHO): Global prevalence and incidence of selected curable sexually transmitted infections: overview and estimates. Geneva: WHO; 2001.

2. Patrick DM: Chlamydia control: Components of an effective control strategy to reduce the incidence of Chlamydia trachomatis. Can J Human Sex 1997, 6: 143-149.

3. Brunham RC, Peeling R, Maclean I, Kosseim ML, Paraskevas M: Chlamydia trachomatis associated ectopic pregnancy: serologic and histologic correlates. J Infect Dis 1992, 165: I076- I08I.

4. Toye B, Laferriere C, Claman P, Jessamine P, Peeling R: Association between antibody to the chlamydial heat-shock protein and tubal infertility. $J$ Infect Dis 1993, 168:1236-1240.

5. Dutta R, Jha R, Salhan S, Mittal A: Chlamydia trachomatis-specific heat shock proteins 60 antibodies can serve as prognostic marker in secondary infertile women. Infection 2008 in press.

6. Beatty WL, Byrne GI, Morrison RP: Morphologic and antigenic characterization of interferon gamma-mediated persistent Chlamydia trachomatis infection in vitro. Proc Natl Acad Sci USA 1993, 90:3998-4002.

7. Beatty WL, Morrison RP, Byrne GI: Immunoelectron-microscopic quantitation of differential levels of chlamydial proteins in a cell culture model of persistent Chlamydia trachomatis infection. Infect Immun 1994, 62:4059-4062.

8. Beatty WL, Byrne GI, Morrison RP: Repeated and persistent infection with Chlamydia and the development of chronic inflammation and disease. Trends Microbiol 1994, 2:94-98.

9. Witkin SS, Linhares I, Giraldo P, Jeremias J, Ledger WJ: Individual immunity and susceptibility to female genital tract infection. Am J Obstet Gynecol 2000, 183:252-256.

10. Debattista J, Timms P, Allan J, Allan J: Immunopathogenesis of Chlamydia trachomatis infections in women. Fertil Steril 2003, 79:1273-1287.

II. Neuer A, Lam KN, Tiller FW, Kiesel L, Witkin SS: Humoral immune response to membrane components of Chlamydia trachomatis and expression of human $60 \mathrm{kDa}$ heat shock protein in follicular fluid of in-vitro fertilization patients. Hum Reprod 1997, 1 2:925-929.

12. Ault KA, Statland BD, King MM, Dozier DI, Joachims ML, Gunter J: Antibodies to the chlamydial 60 kilodalton heat shock protein in women with tubal factor infertility. Infect Dis Obstet Gynecol 1998, 6:163-167. 
13. Spandorfer SD, Neuer A, LaVerda D, Byrne G, Liu HC, Rosenwaks Z, Witkin SS: Previously undetected Chlamydia trachomatis infection, immunity to heat shock proteins and tubal occlusion in women undergoing in-vitro fertilization. Hum Reprod 1999, 14:60-64.

14. Betsou F, Sueur JM, Orfila J: Serological Investigation of Chlamydia trachomatis Heat Shock Protein 10. Infect Immun 1999, 67:5243-5246.

15. LaVerda D, Albanese LN, Ruther PE, Morrison SG, Morrison RP, Ault KA, Byrne Gl: Seroreactivity to Chlamydia trachomatis Hsp IO correlates with severity of human genital tract disease. Infect Immun 2000, 68:303-309.

16. den Hartog JE, Land JA, Stassen FR, Kessels AG, Bruggeman CA: Serological markers of persistent $C$. trachomatis infections in women with tubal factor subfertility. Hum Reprod 2005 20:986-990.

17. Dadamessi I, Eb F, Betsou F: Combined detection of Chlamydia trachomatis specific-antibodies against the 10 and $60-\mathrm{kDa}$ heat shock proteins as a diagnostic tool for tubal factor infertility: Results from a case-control study in Cameroon. FEMS Immunol Med Microbiol 2005, 45:3 I-35.

18. Witkin SS, Jeremias J, Toth M, Ledger WJ: Proliferative response to conserved epitopes of the Chlamydia trachomatis and human 60-kilodalton heat-shock proteins by lymphocytes from women with salpingitis. Am J Obstet Gynecol 1994, I 7 I:455-460.

19. Kinnunen A, Molander P, Morrison R, Lehtinen M, Karttunen R, Tiitinen A, Paavonen J, Surcel HM: Chlamydial heat shock protein 60-specific $\mathbf{T}$ cells in inflamed salpingeal tissue. Fertil Steril 2002, 77:162-166.

20. Debattista J, Timms P, Allan J, Allan J: Reduced levels of gammainterferon secretion in response to chlamydial $60 \mathrm{kDa}$ hea shock protein amongst women with pelvic inflammatory disease and a history of repeated Chlamydia trachomatis infections. Chlamydia trachomatis 2002, 81:205-2I0.

21. Kinnunen A, Surcel HM, Halttunen M, Tiitinen A, Morrison RP, Morrison SG, Koskela P, Lehtinen M, Paavonen J: Chlamydia trachomatis heat shock protein-60 induced interferon-gamma and interleukin- 10 production in infertile women. Clin Exp Immunol 2003, I 3I:299-303.

22. Cohen CR, Koochesfahani KM, Meier AS, Shen C, Karunakaran K, Ondondo B, Kinyari T, Mugo NR, Nguti R, Brunham RC: Immunoepidemiologic profile of Chlamydia trachomatis infection: importance of heat-shock protein $\mathbf{6 0}$ and interferon-gamma. J Infect Dis 2005, 192:591-599.

23. Tiitinen A, Surcel HM, Halttunen M, Birkelund S, Bloigu A, Christiansen G, Koskela P, Morrison SG, Morrison RP, Paavonen J: Chlamydia trachomatis and chlamydial heat shock protein 60 specific antibody and cell-mediated responses predict tubal factor infertility. Hum Reprod 2006, 21:1533-1538.

24. Vats V, Agrawal T, Salhan S, Mittal A: Primary and secondary immune responses of mucosal and peripheral lymphocytes during Chlamydia trachomatis infection. FEMS Immunol Med Microbiol 2007, 49:280-287.

25. Agrawal T, Vats V, Salhan S, Mittal A: Mucosal and peripheral immune responses to chlamydial heat shock proteins in women infected with Chlamydia trachomatis. Clin Exp Immunol 2007, I 48:46|-468.

26. Rottenberg ME, Gigliotti-Rothfuchs A, Wigzell H: The role of IFNgamma in the outcome of chlamydial infection. Curr Opin Immunol 2002, 14:444-45I.

27. Reddy BS, Rastogi S, Das B, Salhan S, Verma S, Mittal A: Cytokine expression pattern in the genital tract of Chlamydia trachomatis positive infertile women - implication for T-cell responses. Clin Exp Immunol 2004, 137:552-558.

28. Joyee AG, Thyagarajan SP, Rajendran P, Hari R, Balakrishnan P, Jeyaseelan L, Kurien T, STD Study Group: Chlamydia trachomatis genital infection in apparently healthy adult population of Tamil Nadu, India: a population-based study. Int J STD AIDS 2004 I 5:5I-55.

29. Bas S, Muzzin P, Ninet B, Bornand JE, Scieux C, Vischer TL: Chlamydial serology: comparative diagnostic value of immunoblotting, microimmunofluorescence test, and immunoassays using different recombinant proteins as antigens. J Clin Microbiol 200I, 39:1368-1377.
30. Dutta R, Jha R, Gupta S, Gupta R, Salhan S, Mittal A: Seroprevalence of antibodies to conserved region of Chlamydia trachomatis heat shock proteins $\mathbf{6 0}$ and 10 in women in India. $\mathrm{Br} J$ Biomed Sci 2007, 64:78-83.

31. Arno JN, Yuan Y, Cleary RE, Morrison RP: Serologic responses of infertile women to the $\mathbf{6 0 - k d ~ c h l a m y d i a l ~ h e a t ~ s h o c k ~ p r o t e i n ~}$ (hsp60). Fertil Steril 1995, 64:730-735.

32. Morrison RP, Su H, Lyng K, Yuan Y: The Chlamydia trachomatis hyp operon is homologous to the groE stress response operon of Escherichia coli. Infect Immun 1990, 58:270I-2705.

33. Conti P, Kempuraj D, Kandere K, Di Gioacchino M, Barbacane RC, Castellani ML, Felaco M, Boucher W, Letourneau R, Theoharides TC: IL-I0, an inflammatory/inhibitory cytokine, but not always. Immunol Lett 2003, 86:123-129.

34. Martinez JA, King TE Jr, Brown K, Jennings CA, Borish L, Mortenson RL, Khan TZ, Bost TW, Riches DW: Increased expression of the interleukin- 10 gene by alveolar macrophages in interstitial lung disease. Am J Physiol 1997, 273:L676-L683.

35. Yang X, Gartner J, Zhu L, Wang S, Brunham RC: IL- 10 gene knockout mice show enhanced ThI-like protective immunity and absent granuloma formation following Chlamydia trachomatis lung infection. J Immunol 1999, 162:1010-1017.

36. Sato $S$, Hasegawa M. Takehara K. Serum levels of interleukin-6 and interleukin- 10 correlate with total skin thickness score in patients with systemic sclerosis. J Dermatol Sci 200I, 27:140-I46.

37. Higgins DP, Hemsley S, Canfield PJ: Association of uterine and salpingeal fibrosis with chlamydial hsp60 and hsp I0 antigenspecific antibodies in Chlamydia-infected koalas. Clin Diagn Lab Immunol 2005, I 2:632-639.

38. Wang S, Fan Y, Brunham RC, Yang X: IFN-gamma knockout mice show Th2-associated delayed-type hypersensitivity and the inflammatory cells fail to localize and control chlamydial infection. Eur J Immunol 1999, 29:3782-3792.

39. Shemer-Avni Y, Wallach D, Sarov I: Inhibition of Chlamydia trachomatis growth by recombinant tumour necrosis factor. Infect Immun 1988, 56:2503-2506.

40. Darville T, Andrews CW Jr, Rank RG: Does inhibition of tumor necrosis factor alpha affect chlamydial genital tract infection in mice and guinea pigs? Infect Immun 2000, 68:5299-5305.

4I. Naz RK, Butler A, Witt BR, Barad D, Menge AC: Levels of interferon-gamma and tumor necrosis factor-alpha in sera and cervical mucus of fertile and infertile women: implication in infertility. J Reprod Immunol 1995, 29:105-II7.

42. $\mathrm{Ng}$ SC, Gilman-Sachs A, Thaker P, Beaman KD, Beer AE, Kwak-Kim $\mathrm{J}$ : Expression of intracellular ThI and Th2 cytokines in women with recurrent spontaneous abortion, implantation failures after IVF/ET or normal pregnancy. Am J Reprod Immunol 2002, 48:77-86.

43. Kwak-Kim JY, Chung-Bang HS, Ng SC, Ntrivalas El, Manqubat CP, Beaman KD, Beer AE, Gilman-Sachs A: Increased $\mathbf{T}$ helper I cytokine responses by circulating $T$ cells are present in women with recurrent pregnancy losses and in infertile women with multiple implantation failures after IVF. Hum Reprod 2003, 18:767-773.

44. Martínez P, Proverbio F, Camejo MI: Sperm lipid peroxidation and pro-inflammatory cytokines. Asian J Androl 2007, 9: I02-107.

45. Estrada LS, Champion HC, Wang R, Rajasekaran M, Hellstrom WJ, Aggarwal B, Sikka SC: Effect of tumour necrosis factor-alpha (TNF- $\alpha$ ) and interferon-gamma (IFN- $\gamma$ ) on human sperm motility, viability and motion parameters. Int J Androl 1997, 20:237-242.

46. Yi Y, Yang X, Brunham RC: Autoimmunity to heat shock protein 60 and antigen-specific production of interleukin-10. Infect Immun 1997, 65: 1669-1674.

47. Yssel H, Malefyt RDW, Roncarolo MG, Abrams JS, Lahesmaa R, Spits $\mathrm{H}$, de Vries JE: IL- 10 is produced by subsets of human CD4+ $T$ cell clones and peripheral blood T cells. J Immunol 1992, I 49:2378-2384

48. Trinchieri G: Interleukin-10 production by effector $\mathbf{T}$ cells: ThI cells show self control. J Exp Med 2007, 204:239-243.

49. Trinchieri G: Regulatory role of $\mathbf{T}$ cells producing both interferon gamma and interleukin 10 in persistent infection. J Exp Med 200I, 194:F53-F57.

50. Witkin SS, Askienazy-Elbhar M, Henry-Suchet J, Belaisch-Allart J, Tort-Grumbach J, Sarjdine K: Circulating antibodies to a con- 
served epitope of the Chlamydia trachomatis $60 \mathrm{kDa}$ heat shock protein (hsp60) in infertile couples and its relationship to antibodies to $C$. trachomatis surface antigens and the Escherichia coli and human HSP60. Hum Repod 1998, I3:1 I75-I I79.

51. Witkin SS, Jeremias J, Toth M, Ledger WJ: Cell-mediated immune response to the recombinant 57-kDa heat shock protein of Chlamydia trachomatis in women with salpingitis. J Infect Dis 1993, 167:1379-1383.

52. Mehra V, Bloom BR, Bajardi AC, Grisso CL, Sieling PA, Alland D, Convit J, Fan XD, Hunter SW, Brennan PJ, Rea TH, Modlin RL: A major $\mathbf{T}$ cell antigen of Mycobacterium leprae is a $10-k D$ heatshock cognate protein. J Exp Med 1992, I 75:275-284.

53. Launois P, N'Diaye MN, Cartel JL, Mane I, Drowart A, van Vooren JP, Sarthou JL, Huygen K: Fibronectin-binding antigen 85 and the 10-kilodalton GroES-related heat shock protein are the predominant TH-I response inducers in leprosy contacts. Infect Immun 1995, 63:88-93.

Publish with Biomed Central and every scientist can read your work free of charge

"BioMed Central will be the most significant development for disseminating the results of biomedical research in our lifetime. "

Sir Paul Nurse, Cancer Research UK

Your research papers will be:

- available free of charge to the entire biomedical community

- peer reviewed and published immediately upon acceptance

- cited in PubMed and archived on PubMed Central

- yours - you keep the copyright

Submit your manuscript here:

http://www.biomedcentral.com/info/publishing_adv.asp
BioMedcentral 